FACTA UNIVERSITATIS

Series: Economics and Organization Vol. 16, N ${ }^{\mathrm{o}} 3,2019$, pp. 229 - 238

https://doi.org/10.22190/FUEO1903229F

Original Scientific Paper

\title{
UPDATE OF THE CRAWL, WALK, RUN METHODOLOGY FRAMEWORK
}

\author{
UDC 658.8:004
}

\section{Jelena Filipović}

University of Belgrade, Faculty of Economics, Serbia

\begin{abstract}
This study updated the Crawl, Walk, Run methodology framework (CWRM) for the current digital marketing circumstances, observed in the context of the artistic community in virtual space. Four main premises of CRWM have been considered in order to address the effectiveness of online campaigns based on the laddering support through tiers of engagement (personal, social, advocating); empowering super users; providing source materials for user-generated content; and using tools people are familiar with. The analysis was performed on the data collected from the online community which operated for 43 days. Data on the number of registered users, their interactions with web site content and showcased artworks were gathered. The specific online platform was created for the purpose of this research and the campaign for its promotion was conducted both in Serbia and globally. The materials for direct communications (email, instant messaging), social media promotion (social networks, blogs) and public relations (articles in online and traditional media) were created. CRWM was proved to be efficient framework for the establishment of online presence of the artistic community. However, we propose that social networks should be introduced in the stage three instead of in the stage four, due to the increase of their applications compared to the time when the CRWM was formulated. All activities once they start should be maintained and performed throughout the campaign lifetime. This study represents one of the first efforts aimed at updating the CRWM theoretical framework and provides business community with hands-on solutions in modern digital marketing.
\end{abstract}

Key words: online community; crawl, walk, run methodology; arts; digital marketing

JEL Classification: M15, M31

Received March 04, 2019 / Revised June 18, 2019 / Accepted June 24, 2019

Corresponding author: Jelena Filipović

University of Belgrade, Faculty of Economics, Kamenička 6, 11000 Belgrade, Serbia

E-mail: jfilipovic@ekof.bg.ac.rs 


\section{INTRODUCTION}

Online advertising has been constantly on the growth and its revenues have exceeded the level of $\$ 20$ billion yearly (Shaouf, $\mathrm{Lü} \mathrm{\&} \mathrm{Li}, 2016$ ). In China in 2011 web advertising surpassed the newspaper advertising revenue for the first time ever (Zha, Li \& Yan, 2015), while it is predicted that in 2019 digital ad spending will exceed traditional in the USA (eMarketer, 2019). In Serbia the value of the digital advertising market amounted to $€ 18.16$ million in 2014 (Filipovic, 2017, p. 80). In the last decade we have testified to the strong surge in social media marketing usage and relevance (Shareef et al., 2019). Nevertheless, the term social media marketing covers a broad range of strategies and techniques which can significantly vary in their effectiveness in communication with target groups (Willis, 2019). The main aims of all of them are to incite and reinforce consumers' engagement (Tuten \& Mintu-Wimsatt, 2018).

Despite its relevance and numerous scientific and professional studies that have been conducted in the field of digital business, there is still a paucity of research which propose methodologies and analyze effectiveness of the online campaigns, especially in the field of social media, given the novelty of this concept. In order to reflect the changes of the media landscape and promotional opportunities arisen from the technological development, the methodology framework "Crawl, Walk, Run“ (CWRM) was developed by the Lutz and Edelman team in 2009 and tested in subsequent studies (e.g. Aaker \& Chang., 2009). The aim of this study is to update the current understanding of CRWM and explore its applicability in the modern social media circumstances.

\section{LITERATURE REVIEW}

In general, there is still a debate among scholars of modern theory of advertising on the extent of influence of advertising on consumer behaviour (Ognjanov, 2013, p. 180). Furthermore, there is also an issue of the effects of advertising on consumers' attitudes, knowledge and shopping patterns. According to their nature, all models can be divided into two groups: i) advertising impacts individuals in predetermined order of stages; ii) effects may occur simultaneously and not in the specific sequence (Ognjanov, 2013, p. 182). Both types of models need to be revised, as Wijaya (2012, p. 73) pointed out "the development of information technology has radically changed the way of how people communicate and socialize; as well as a paradigm shift from product-oriented marketing to consumer-oriented marketing or people-oriented marketing. Therefore, the variables in the hierarchy of effects model needs to be updated..."

The „Crawl, Walk, Run model” (CWRM) proposes appropriate social media tools for public engagement in different stages of the campaign. According to the Lutz \& Edelman team (2009) there are ten characteristics of a successful online campaign: "laddering support through tiers of engagement (personal, social, advocating); empowering super users; providing source materials for user-generated content; going where the people are, using tools people are familiar with, ensuring that people can find your content, mobilizing supporters through mobile devices, harnessing analytics to constantly improve engagement activities, building the online operation to scale and choosing the right team". Notwithstanding importance of all of them and of their interrelations, we particularly explored the ones which are significant for the short term campaigns and virtual social community. More specifically, these are: laddering support through tiers of engagement; 
empowering super users; providing source materials for user-generated content; and using tools people are familiar with. These four premises have been investigated in our study and the results are demonstrated in the following sections.

CWRM has been efficiently utilized in the investigation in numerous sectors: nonprofit (Berkman, 2013), industry (Debes et al., 2007; Vitas, 2013), army (Meliza \& Barnett, 2006; Florio et al., 2010), finances (Raisinghani, 2006), branding (Neitzel, 2015), interactive television (Jensen, 2005) and many others and proved its relevance over time. Despite the emergence of other frameworks in digital marketing over time, such as: RACE (reach, act, convert, engage), CDJ (consumer decision journey), PESO (paid, earned, shared, owned media), etc., some of the leading companies utilize CWRM in their current digital marketing approach (Kerr \& Moloney, 2018), while scholars (e.g. Berman \& Thelen, 2018) argue its theoretical credibility. However, it should be noted that some updates of CWRM are needed, due to the arrival of some of the new digital marketing tools (compared to 2009 when this concept was established), the acceleration of changes in business environment and burst of global competition in the web space. In these terms, this paper strives to update CWRM and to help its better application in the modern state of affairs of digital marketing.

In nowadays media landscape there are hundreds of social media sites that target smaller groups of users with specific interests. One of the groups of users which has drawn considerable attention in the previous period is the community of artists and artisans. The crafting market is estimated to be worth $\$ 100$ billion annually on the global scale (PYMNTS, 2017). The relevance of the online community for this sizeable market can be understood from the fact that LoveCrafts, the UK-headquartered marketplace for craft products, has raised \$33 million in 2017 in new funding from Scottish Equity Partners, as well as previous investors Balderton Capital and Highland Europe (Cook, 2017). LoveCrafts runs two online communities: knitting and crochet. Users can follow each other and purchase designs for knitting and crochet projects, while the platform takes a cut of the cost of designs, as well as any of the crafting supplies sold through the site.

The other case of the global significance of the artists' and crafters' global community is the social network DeviantArt, which has gathered more than 40 million registered members and showcased over 325 million pieces of original art. Israel-based Wix.com acquired DeviantArt in 2017 for $\$ 36$ million in cash (Reuters, 2017). The importance of socializing tools on such online platforms are best reflected by the example of the results of Dribbble, where in 2017, designers showed off over 640 thousand of shots of their work, and the community responded with over 27 million likes and 925 thousand comments (Dribbble, 2017).

Artistic and „do it yourself“ (DIY) virtual communities have attracted considerable attention of researchers in various fields. Some of the research areas in which online groups related to arts and DIY are represented are: culture (Spero \& Stone, 2004, Kuznetsov \& Paulos, 2010; Hall \& Jayne, 2016), gender studies (Bratich \& Brush, 2011), ecology (Cervellon \& Wernerfelt, 2012), politics (Harris, 2008), media (Lingel \& Naaman, 2012) and marketing (Liss-Marino, 2014; Chen \& Chandler, 2010; Wu \& Fang, 2010).

The aim of this research is to re-examine the potency of CWRM in the introduction of a new artistic community to the global virtual space. In the following section of the paper the adopted methods are explained thoroughly, while the subsequent chapters detail on the results that have been obtained and relevance of the study both for scholars and for managers. 


\section{METHODS}

For the purpose of this research, a specific web site was registered and developed. In order to reach wider audience, the web site was created in English and indexed under the global domain name www.TalentsFair.com. The aim of the platform was to attract artists and artisans to exhibit their works and establish their online portfolios. Moreover, the web site also addressed general public who was interested in arts and who wanted to take part in browsing, commenting and voting for various content.

The landing page of the website included large picture of logo (artistically designed star), name of the website (Talents Fair), its credo (,You got it, show it!“) and categories of artistic works that could be submitted. The picture of the first page and the typical page of the web site is depicted in Figure 1. The prevailing colour of the whole web site (including the landing page) was yellow.
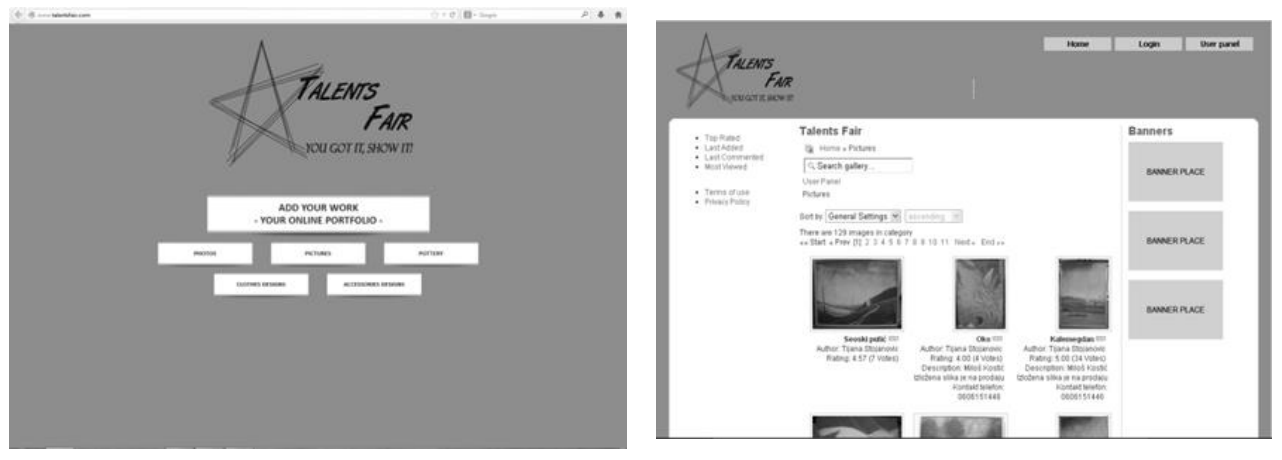

Fig. 1 Pages of the experimental website Talents Fair

There were five different categories of artistic works whose pictures could be presented - these are: photos, paintings, pottery, clothes designs and accessories designs. Accessories mainly pertain to jewellery, but also included: hats, bags, boxes, glasses and other fashion pieces. In order to mimic real (i.e. non-experimental) web sites to the highest extent, the subject platform also included sections on Terms of Use and Privacy Policy, as well as the banner spaces as a part of promotional opportunities for advertisers.

Only registered users were able to display their work, therefore, the first step was to open their account and create a profile, by providing their name, user name and email address. After that, they were granted the right to log in. The users accessed the area for the showcase of their work (virtual gallery) through the „User panel“. In this section they could upload their pieces and provide necessary details, e.g. the name of the creation or its description (for instance, if it is for sale, contact details, etc.).

The web site construction encompassed some widgets too. These interaction tools included: browsing content in the gallery („Previous“ and „Next“" arrows), commenting and scoring (scale 1-5) of each of the exhibits. Furthermore, all users could observe Top rated, Most viewed, Last commented and Last added content. The links for the listed categories were presented in the top left part of the page, allowing shortcuts and efficient paths for users. 
The experiment lasted 43 days, while the relevant results of its usage are presented in the following chapter. In accordance to ethic rules, the relevant parties were notified of the experimental nature of the web site and its limited lifetime. Given the aim of the research, only online media were used for the promotion, while offline media were not involved. The experiment acted on the null budget principle, allocating no budget for promotional activities. Hence, only free promotional tools were used, mainly relying on social networks. It should be noted that even though the banner space was presented on the web site, its rental was not foreseen within the experiment. In any manner, no request for advertising was received throughout the project's lifetime.

\section{RESULTS AND DISCUSSION}

In the analysis we will examine the effectiveness of the Crawl, Walk, Run Methodology (CWRM) for the social media and investigate whether proposed online tools in each stage result in the expected outcomes.

Table 1 Crawl, Walk, Run Methodology framework

\begin{tabular}{lllll}
\hline \multicolumn{1}{c}{ CRAWL } & \multicolumn{1}{c}{ WALK } & \multicolumn{2}{c}{ RUN } & \multicolumn{1}{c}{ FLY } \\
\hline $\begin{array}{l}\text { Establish an online } \\
\text { presence }\end{array}$ & Enrich content & $\begin{array}{c}\text { Engage online } \\
\text { influencers }\end{array}$ & Embrace community \\
\hline - Web site & - Podcasting & - Blogger Outreach & - Blogger tours \\
- Conversation audit & - Video & - Blogger conference & - Thought leadership \\
& - Games & calls & blog \\
& - Widgets & - Advertising & - Social networks \\
& & - Ally development & - Advocacy \\
& & - Sponsorships & - Contests \\
& & & - Mobile \\
\hline
\end{tabular}

\footnotetext{
Source: Lutz \& Edelman team (2009), The Social Pulpit, Edelman, p. 11, https://cyber.harvard.edu/sites/cyber.harvard.edu/files/Social\%20Pulpit\%20\%20Barack\%20Obamas\%20Social\%20Media\%20Toolkit\%201.09.pdf
}

In the first phase of the span of the social media campaign, the model foresees the introduction of the media content in the virtual space. Therefore, the website www.TalentsFair.com was launched, under the global domain. Previous inspection of the online sources (e.g. DeviantArt, Styleportfolios, Artlog, etc.), which was a sort of a conversation audit, concluded that terms such as ,talent“ and „fair" were associated with arts, artistic portfolios, purchase and other aspects embedded in the main vision and orientation of the subject web site.

The stage demarcated as „Walk“ means populating the website with content. Taking into account the peculiar type of the web site (user generated content), this is comprehended in twofold manner: users should be attracted to open their profiles and they need to be incited to showcase their work, by adding their content to the platform. Overall, 348 users registered (created their profiles) and submitted 767 different works (Artistic photos: 227; Paintings: 130; Pottery: 80; Clothes: 72; Accessories: 258). 
Moreover, widgets for voting were utilized, resulting in 512 comments on the website, while the top rated content was the picture of a forest, which scored 4.88 (scale 1-5) based on 1561 votes. Many other content raised significant interest by the target groups, e.g.: the painting of a dancer (score: 4.99; 401 votes); the sculpture by Magdalena Pavlovic (score: 4.96; 316 votes), ballet costumes (score: 4.97; 145 votes), a graphic by a professor (score: 4.98; 142 votes), etc.

The third and fourth stages were performed simultaneously, given that both of them aim to reach the target group. Therefore, in this phase, the users were attracted mainly by social networks, namely by the posts on Facebook, Twitter, Instagram, YouTube, Skyrock and direct contacts through Viber and Whatsapp. Even though the CWRM proposed by the Lutz and Edelman team (2009) did not list social networks as the tool within the third stage, we assumed that it was due to the date the CWRM was established, while social network ecosystem and its significance have grown greatly from that time up to nowadays.

The engagement of online influencers mostly occurred by direct communication either personal (face to face and telephone) or by direct online media, such as email, Skype and instant messaging on social networks. CWRM suggests that the emphasis should be put on stimulating bloggers, regarded as the dominant influencers in the virtual sphere, to take part in the web site activity. Table 2 depicts some of the influencers in each category whose reputation and exhibition of the works on the platform were estimated to have positively affected the web site performance.

Table 2 Influencers who engaged in the web site performance

\begin{tabular}{|c|c|c|c|c|}
\hline $\begin{array}{l}\text { Accessory } \\
\text { design }\end{array}$ & Clothes design & Paintings & Photos & Pottery \\
\hline Maruska nakit & Kostimi - kreator Rada & Jovica Poguberov & Milica Djeric & Magdalena Pavlovic \\
\hline UNA nakit & Diline Haljine & Dragan Petkovic & Istok Pavlovic & Stefan Stankovic-Peric \\
\hline Chicamote & Gingerita T-shirt & Milos Kostic & Ivan Josifovic & Ljubica design \\
\hline $\begin{array}{l}\text { Torbice za } \\
\text { frajlice }\end{array}$ & $\begin{array}{l}\text { D-fashion by Danijela } \\
\text { Zujic }\end{array}$ & Tijana Stojanovic & & Etnopark Terzic Avlija \\
\hline $\begin{array}{l}\text { Wa Wa Woom } \\
\text { design }\end{array}$ & $\begin{array}{l}\text { Svetlana Blagojevic i } \\
\text { Georgeone Essi }\end{array}$ & Branka Cvorovic & & Aleksandar Mitrovic \\
\hline
\end{tabular}

However, in the modern media landscape, we considered that social networks influencers should be regarded at the same level of importance. Testing that assumption, online communities were reached in the specialized groups on social networks (Table 3). Results demonstrated that ,ally development“ and ,social networks involvement“ may encompass the same set of activities, especially in terms of advocacy. This outcome also reinforces the hypothesis that the last two stages of the model need to be conducted parallelly rather than consecutively.

Table 3 Ally programmes - posts on the established social media groups

\begin{tabular}{lccr}
\hline Facebook & Number of members (likes) & Twitter & Number of followers \\
\hline Novecento Cipele Beograd & 160,000 & Smajli & 2,332 \\
DressCode & 60,752 & Lauro Pedraza & 1,056 \\
Kreativnost & 40,046 & UNA nakit & 274 \\
Elm Jewelry & 31,903 & Kreativnost & 105 \\
Diotima & 14,297 & & \\
\hline
\end{tabular}


Since public relations activities have not been specifically stipulated in the CWRM, it might be supposed that they were blended with advocacy, sponsorship and advertising. Thus, articles and posts regarding TalentsFair are published in: a) online journals: WANNABE magazine and Prave novine; and b) print magazines: Style magazine and MonopolList. Many other media were contacted, both traditional and interactive, as well as many associations which gather professionals from target groups (e.g., painters, photographers, sculptors, etc.), but they showed no interest in participating in the work or promotion of this online community.

Finally, as it has already been explained in the previous section, the web site was created in English, in order to be able to reach global audience. During the project lifetime, the promotional information on TalentsFair was published in several languages by diverse web authors: Lauro Pedraza Visual Artist, Partito Artisti del Mondo, Alex Art Works, Portrety na zamówienie - Monika Malinowska, Phanères bijoux, International Art Contest, Nina's fashion show and blog.dnevnik.hr.

\section{CONCLUSIONS}

It should be noted that the first two phases last significantly less than the last two phases. Dominantly it is due to the fact that they include many preparatory activities, usually performed before the official start of the campaign. However, this does not affect the relevance of the former stages compared to the latter ones, given that the level of their quality will highly determine the overall success or failure of the campaign.

It is significant to observe that the first two stages are web site directed, while the second two are user oriented. In fact, the establishment of the online presence and upgrade of its content can be considered as the work on the organization's offer and online product, whereas the involvement of the opinion leaders (influencers and allies) and community is targeted to obtain consumers. Provided that these two spheres cannot exist independently, it may be concluded that the CWRM should be updated to be organized as a simultaneous rather than a sequential model.

All activities once they start should be maintained and performed throughout the campaign lifetime. For instance, website maintenance and continuous enriching the content are of substantial importance for the success of the whole campaign. In line with recent changes and trends in the online communications, the authors propose the obligatory introduction of the social media presence in the list of tools listed in the stage of "Walk“. Mainly, it should be addressed by enabling the sharing of the content on the website on social media platforms, primarily by including appropriate widgets for that purpose in the online platform. Similarly to our observation related to social networks, the proposition based on the results of our study is also to include "thought leadership blog" in the third instead of the fourth phase. In the Serbian market, opinion leaders in virtual space usually coincide with professionals in the subject domain in real life.

In addition, in the context of the subject web site, the use of the visually specialized social media, such as Instagram and Pinterest, potentially could improve the effects. This assumption should be addressed by some further studies, exploring the different channels for enriching the content and enhancing the performances based on the nature (verbal vs. visual vs. multimedia) of the online platform. Given that the authors of the CWRM (Lutz 
\& Edelman team, 2009) recommended only multimedia tools, which contain audio, video and user-performed content, we suggest that this list should be extended to incorporate tools that demand lower level of users' involvement, compared to theirs. More specifically, provided the shrinking of users' available time and concentration span, they should be enabled to participate less extensively, through tools, such as: voting (like, dislike, scoring, etc.), commenting, browsing the content, etc.

The lack of interest by established traditional media to promote new initiatives may suggest that there is still a gap between traditional and digital media. However, it may also occur due to the great number of news that compete for limited media space. This notion might also explain why digital media were more prone to participate in the promotion of TalentsFair, given that digital space has been inexhaustive and they understood to a higher extent, than their traditional counterparts, the importance of provision of PR to new online businesses.

The scarcity of support by professional associations probably was grounded in the understanding of the determined project lifetime and not yet established reputation, due to its novelty, of the web site. Further studies should investigate willingness of professional associations to help the growth of confirmed web sites which contain artistic portfolios. Its potential for wider international reach can be examined both from the perspective of the brand reputation, as well as from the point of view of (limited vs. unlimited) duration of web site.

Some limitations of this study should also be considered. Firstly, the duration of the experiment was quite short and all phases of the CWRM were executed in condensed form. Future research should review the possibility of undertaking longer experiments. Secondly, mobile communications, even though they are proposed in the model, were not addressed by this study due to the lack of resources. Taking into account the substantial growth of this kind of communications, further studies should consider testing of the mobile versions of online platforms too. Finally, rather limited international grasp and impact were made, despite the international character of both the media (i.e. the Internet) and the tool (i.e. the web site in English).

However, given that this study represents one of the first efforts aimed at updating the CWRM theoretical framework, as well as its orientation toward exploration of the globally soaring handicrafts and artistic online communities, it is supposed to serve as a relevant point of reference for future research in the subject field.

\section{REFERENCES}

Aaker, J. \& Chang, V. (2009). Obama and the Power of Social Media and Technology. Retrieved from https://www.gsb.stanford.edu/faculty-research/case-studies/obama-power-social-media-technology, Accessed on: 16 January 2019.

Bateman, P.J., Gray, P.H. \& Butler, B.S. (2011). Research note-the impact of community commitment on participation in online communities. Information Systems Research, 22 (4), 841-854. https://doi.org/ 10.1287/isre. 1090.0265

Berkman, R. (2013). Nonprofits get more from social media with metrics. MIT Sloan Management Review, 55 (1), 1-5.

Berman, B. \& Thelen, S. (2018). Planning and implementing an effective omnichannel marketing program. International Journal of Retail \& Distribution Management, 46 (7), 598-614.

Bratich, J.Z. \& Brush, H.M. (2011). Fabricating activism: Craft-work, popular culture, gender. Utopian studies, 22 (2), 233-260. DOI: 10.5325/utopianstudies.22.2.0233 
Cervellon, M.C. \& Wernerfelt, A.S. (2012). Knowledge sharing among green fashion communities online: Lessons for the sustainable supply chain. Journal of fashion marketing and management: An international journal, 16 (2), 176-192. DOI: 10.1108/13612021211222860

Chen, S. \& Chandler, J.D. (2010). Design it, your self-experiences (DIY): Social creativity and the social function of DIY experiences. ACR North American Advances.

Cook, J. (2017). LoveCrafts raised $£ 26$ million for its online crafting communities. Retrieved from http://uk.businessinsider.com/lovecrafts-raised-26-million-scottish-equity-partners-online-craftingcommunities-2017-4, Accessed on: 16 January 2019.

Debes, E., He, J., Kaine, G., Lu, M. \& Yeluri, R. (2007). Usage-Based Platform Design: Case Studies in Thermal Design, Enterprise Manageability, and Information Access. Intel Technology Journal, 11 (1), 35-44.

Dribbble (2017). Dribbble 2017 Year In Review. Retrieved from https://dribbble.com/2017, Accessed on: 20 January 2019.

eMarketer (2019). US Digital Ad Spending Will Surpass Traditional in 2019. Retrieved from https://www.emarketer.com/content/us-digital-ad-spending-will-surpass-traditional-in-2019, Accessed on: 14 June 2019

Filipovic, J. (2017). Internet marketing. Beograd: CID Ekonomskog fakulteta

Florio, M., Hotop, D., Groves, S., Davis, K. \& Farrll, R. (2010). Connecting the Force from Space: The IRIS Joint Capability Technology Demonstration. Army space and missile defense command/army forces strategic command Peterson AFB CO., http://www.dtic.mil/dtic/tr/fulltext/u2/a559469.pdf

Hall, S. M. \& Jayne, M. (2016). Make, mend and befriend: geographies of austerity, crafting and friendship in contemporary cultures of dressmaking in the UK. Gender, Place \& Culture, 23 (2), 216-234. DOI: 10.1080/0966369X.2015.1013452

Harris, A. (2008). Young women, late modern politics, and the participatory possibilities of online cultures. Journal of youth studies, 11 (5), 481-495. DOI: 10.1080/13676260802282950

Jensen, J.F. (2005, November). Interactive television: new genres, new format, new content. In Proceedings of the second Australasian conference on Interactive entertainment (pp. 89-96). Creativity \& Cognition Studios Press.

Kerr, W. R. \& Moloney, E. (2018). Vodafone: Managing Advanced Technologies and Artificial Intelligence, Retrieved from: https://www.alumni.hbs.edu/Documents/events/2018/Vodafone_Case_and_Discussion_ Questions.pdf, Accessed on: 17 June 2019

Kuznetsov, S. \& Paulos, E. (2010, October). Rise of the expert amateur: DIY projects, communities, and cultures. In Proceedings of the 6th Nordic Conference on Human-Computer Interaction: Extending Boundaries (pp. 295-304). ACM, DOI:10.1145/1868914.1868950

Lingel, J. \& Naaman, M. (2012). You should have been there, man: Live music, DIY content and online communities. New Media \& Society, 14 (2), 332-349. DOI: 10.1177/1461444811417284

Liss-Marino, T.J. (2014). Sell (it) yourself: Marketing pleasure in digital DIY, Retrieved from https://repository.upenn.edu/edissertations/1347, Accessed on: 16 January 2019.

Lutz, M. and Edelman team (2009), The Social Pulpit, Edelman, Retrieved from https://cyber.harvard.edu/ sites/cyber.law.harvard.edu/files/Social\%20Pulpit\%20-\%20Barack\%20Obamas\%20Social\%20Media\% 20Toolkit\%201.09.pdf

Meliza, L.L. \& Barnett, J.S. (2006). Tailoring an Information Flow Model to Trainee Level of Proficiency. Army research institute for the behavioral and social sciences Orlando FL., http://www.dtic.mil/dtic/tr/ fulltext/u2/a482740.pdf

Neitzel, J. (2015). Sustainable sourcing to innovate a private brand. Journal of Brand Strategy, 4 (2), 154-160.

Ognjanov, G. (2013). Marketinske komunikacije [Marketing communications]. Beograd: CID Ekonomskog fakulteta

PYMNTS (2017). Retrieved from Lovecrafts Grabs \$33M In New Funding. https://www.pymnts.com/news/ retail/2017/lovecrafts-grabs-33m-in-new-funding/, Accessed on: 21 February 2019.

Raisinghani, M.S. (2006). An Interview with Uttiya Dasgupta. Journal of Information Technology Case and Application Research, 8 (4), 61-64.

Reuters (2017). Israel's Wix buys DeviantArt for $\$ 36 \mathrm{mln}$, raises revenue outlook. Retrieved from http://www.businessinsider.com/r-israels-wix-buys-deviantart-for-36-mln-raises-revenue-outlook-2017-2, Accessed on: 20 January 2019.

Shaouf, A., Lü, K. \& Li, X. (2016). The effect of web advertising visual design on online purchase intention: An examination across gender. Computers in Human Behavior, 60, 622-634. DOI:10.1016/j.chb.2016. 02.090 
Shareef, M.A., Mukerji, B., Dwivedi, Y.K., Rana, N.P. \& Islam, R. (2019). Social media marketing: Comparative effect of advertisement sources. Journal of Retailing and Consumer Services, 46, 58-69, DOI: $10.1016 /$ j.jretconser.2017.11.001

Spero, I. \& Stone, M. (2004). Agents of change: how young consumers are changing the world of marketing. Qualitative Market Research: An International Journal, 7 (2), 153-159, DOI: 10.1108/13522750410530057

Tuten, T. \& Mintu-Wimsatt, A. (2018). Advancing our understanding of the theory and practice of social media marketing: Introduction to the special issue. Journal of Marketing Theory and Practice, 26 (1-2), 13, DOI: 10.1080/10696679.2018.1393277.

Vitas, B. (2013). Community-driven information quality standards: How IBM developed and implemented standards for information quality. Technical Communication, 60 (4), 307-315.

Wijaya, B.S. (2012). The development of hierarchy of effects model in advertising. International Research Journal of Business Studies, 5 (1), 73-85. DOI: 10.21632/irjbs.5.1.73-85

Willis, M. (2019). The Dynamics of Social Media Marketing Content and Customer Retention. In Leveraging Computer-Mediated Marketing Environments (pp. 1-21). IGI Global. DOI: 10.4018/978-1-5225-73449.ch001

Wu, S.C. \& Fang, W. (2010). The effect of consumer-to-consumer interactions on idea generation in virtual brand community relationships. Technovation, 30 (11-12), 570-581, DOI:10.1016/j.technovation.2010. 07.005

Zha, X., Li, J. \& Yan, Y. (2015). Advertising value and credibility transfer: attitude towards web advertising and online information acquisition. Behaviour \& Information Technology, 34 (5), 520-532. DOI: 10.1080/ 0144929X.2014.978380

\section{AŽURIRANJE METODOLOŠKOG OKVIRA "PUZI, HODAJ, TRČI"}

Predmet istraživanja ove studije je ažuriranje metodologije "Puzi, hodaj, trči” (PHTM) u savremenim okolnostima digitalnog marketinga, posmatrano u kontekstu umetničke zajednice $u$ virtuelnom prostoru. Razmotrene su četiri glavne premise PHTM-a kako bi se testiralo da li bi onlajn kampanje mogle postići uspešne rezultate kroz: faznu podršku kroz različite nivoe angažovanja (lične, društvene, zastupničke); osnaživanje super korisnika; obezbeđivanje materijala za sadržaj koji generišu korisnici; i korišćenje alata sa kojima su korisnici upoznati. Analiza je izvršena na podacima prikupljenim iz onlajn zajednice koja je bila aktivna 43 dana. Prikupljeni su podaci o broju registrovanih korisnika, njihovim interakcijama sa sadržajem veb stranica i materijalima (umetničkim radovima) koji su bili izloženi na sajtu. Za potrebe ovog istraživanja napravljena je posebna onlajn platforma, a kampanja za njenu promociju sprovedena je kako u Srbiji, tako i globalno. Kreirani su materijali za: direktne komunikacije (imejl, instant mesindžer), promociju na društvenim medijima (društvene mreže, blogovi) i odnose s javnošću (članci u onlajn i tradicionalnim medijima). PHTM se pokazao kao efikasan okvir za uspostavljanje onlajn prisutnosti umetničke zajednice. Međutim, predlažemo da se društvene mreže uvedu u trećoj umesto u četvrtoj fazi, s obzirom na povećanje opsega njihovih funkcija u odnosu na vreme kada je PHTM formulisan. Sve započete aktivnosti treba održavati i izvoditi tokom čitavog trajanja kampanje. Ova studija predstavlja jedan od prvih napora $u$ cilju ažuriranja PHTM teorijskog okvira i pruža poslovnoj zajednici praktična rešenja u modernom digitalnom marketingu.

Ključne reči: onlajn zajednica; puzi, hodaj, trči metodologija; umetnost; digitalni marketing 